Bahşi, N. ve Sis, N. (2019). Ortaokul öğrencilerinin cümle, paragraf ve metin oluşturma düzeyi üzerinde etkili olan değişkenler. Ana Dili Eğitimi Dergisi, 7(3), 553-573.

$\begin{gathered}\text { Ana Dili Eğitimi Dergisi } \\ \text { Journal of Mother Tongue Education } \\ \text { www.anadiliegitimi.com }\end{gathered}$
$\begin{gathered}\text { Geliş/Received: } 26.03 .2019 \text { Kabul/Accepted:06.05.2019 } \\ \text { Arasstrma Makalesi / Research Paper }\end{gathered}$
Öğrencilerinin Cümle, Paragraf ve Metin Oluşturma Düzeyi Üzerinde Etkili Olan
Değişkenler

\title{
Ortaokul Öğrencilerinin Cümle, Paragraf ve Metin Oluşturma Düzeyi Üzerinde Etkili Olan Değişkenler*
}

\author{
Niymet BAHŞi** \\ Nesrin SiS $^{* * *}$
}

\begin{abstract}
Öz
Bu çalışmada, ortaokul öğrencilerinin cümle, paragraf ve metin oluşturma düzeyleri üzerinde etkisi olan değişkenler tespit edilmiştir. Bu araştırmanın örneklemini Malatya merkez ilçe ortaokullarında öğrenim gören 5 ve 8 . sınıf öğrencileri oluşturmuştur. Araştırmada veri toplama aracı olarak "Kişisel Bilgi Formu" ve araştırmacı tarafından geliştirilen "Yazılı Anlatım Düzeyini Belirlemek İçin Kullanılan Dereceli Puanlama Anahtarı" kullanılmışır. Araştırmada, öğrencilerin yazılı anlatımlarında nicel değerlendirme yapılımışır. Araştırmada elde edilen veriler araştırmanın alt amaçları doğrultusunda parametrik testler olan tek yönlü ANOVA ve ilişkisiz (bağımsız) örneklemler için $t$-testi analizleri kullanılarak test edilmiştir. Söz konusu bulgular neticesinde 5 ve 8.sınıf düzeyinde öğrenim gören öğrencilerin yazılı anlatım düzeyleri üzerinde cinsiyetin, sınıf düzeyinin, evlerinde kitaplık olma durumunun, sosyo- ekonomik durumun, annenin eğitim düzeyinin, babanın eğitim düzeyinin ve eve süreli yayın alma sıklığının anlamlı etkisinin olduğu tespit edilmiştir
\end{abstract}

Anahtar Kelimeler: Yazma eğitimi, yazma düzeyi, nicel çalışma.

\section{The Variables that Affect Sentence, Paragraph and Text Formation Levels of Middle School Students}

\begin{abstract}
The present study aimed to determine the variables that affect sentence, paragraph and text formation levels of middle school students. The study sample included 5th and 8th grade students attending middle schools at Malatya province central district. Personal Information Form and "Grade Score Key to Determine Written Expression Levels" scale, developed by the author, were used to collect the study data. In the study, written expressions of the students were analyzed with quantitative methods. The study data were tested with one-way ANOVA, a parametric test, and independent samples t-test analysis. The study findings that there was a significant impact of gender, grade level, presence of a library at home, socio-economic level, mother's education level, father's education level and frequency of purchasing periodicals on written expression levels of 5 th and 8th grade students.
\end{abstract}

Keywords: Writing education, writing level, quantitative study

\footnotetext{
* Bu makale 2018 Kasımda İnönü Üniversitesi Eğitim Bilimleri Enstitüsünde Niymet Bahşi tarafından sunulan “Ortaokul Öğrencilerinin Yazma Düzeyleri ve Yazılarında Karşılaşılan Sorunlar (Malatya ili örneği)" adlı doktora tezinden hazırlanmıştır

** Dr, İnönü Üniversitesi, Malatya, niymet44@hotmail.com, ORCID: 0000-0002-9115-5432

*** Prof. Dr. İnönü üniversitesi Eğitim Fakültesi Türkçe Eğitimi Bölümü, Malatya, nesrin.sis@inonu.edu.tr, ORCID: 0000-0002-2743-3397
} 


\section{Giriş}

Sembollerden oluşan yazı; insanoğlunun vazgeçilmez iletişim araçlarından biridir. Yazı bilginin kalıcılığını sağlamakta, kültürel değerleri kuşaktan kuşağa aktarmaktadır. Aynı zamanda bireylerin, toplumların gelişmesini sağlayan önemli bir araçtır.

Yazılı anlatım, bireyin kendisini doğru ve amacına uygun ifade etmesini sağlar. Duygularımızı, düşüncelerimizi, hayallerimizi çeşitli şekillerde insanlarla paylaşırken kullandığımız iletişim yollarından biri de yazmadır. Binyazar ve Özdemir (2006: 15-19) yazma gereksiniminin kişisel, toplumsal ve uğraşsal zorunluluktan doğduğunu belirtir.

Yazma, duygu ve düşüncelerin semboller yoluyla ifade edilmesidir. Bireylerin günlük yaşamda yazma becerisini kazanıp etkili olarak kullanması için bu alanda belli bir düzeyde eğitim alması gerekmektedir. Keçik ve Uzun (2001), dünyaya geldikten sonra ilk beş yıl içinde ana dili ediniminin gerçekleştiğini, buna karşın yazmanın öğrenilemediğini ve dilin yazı ile gösteriminin okulda verilen eğitimle gerçekleştiğini belirtmiştir.

Okulda alınan eğitim, bireyde belli bir düzeyde teknik olarak altyapı oluşturur. Bireyin çabasıyla da şekillenmeye devam eden yazma becerisinin gelişimi, ömür boyu devam eder.

Eğitimin ilk kademesinde öğrencilere temel okuryazarlık becerileri kazandırılmaya çalışılır, daha sonraki yıllarda ise öğrencilerin temel dil becerilerini geliştirmeye dönük çalışmalar yaptırılır. Yazma becerisinin geliştirilme sürecinde ise bireylerin kendilerini yazılı olarak ifade etmesi hedeflenir

Ana dil öğrenimi eğitim sisteminin temelini oluşturmaktadır. Okuduğunu, dinlediğini anlamayan, anladıklarını sözlü veya yazılı olarak ifade edemeyen bir öğrencinin diğer derslerde de başarısız olması kaçınıımazdır.

Karaalioğlu (1978: 68), Türkçe öğretiminde; bir öğrencinin ne derece ilerlediğinin, yazılı kompozisyonundan; bildiklerini, gördüklerini, duyduklarını, düşündüklerini doğru, etkili, açık bir biçimde anlatıp anlatmamasından anlaşıldığını belirtir. Aynı zamanda yazılı anlatım becerileri okul yaşamındaki başarının temelini oluşturur. Bu konuya dikkat çeken Temur (2001: 13), öğrencilerin yazılı anlatımlarıyla matematik, fen bilgisi, sosyal bilgiler ders başarısı arasında anlamlı bir ilişkinin var olduğunu saptamıştır.

Yazma; ilkokuldan yükseköğrenime, iş hayatından sosyal hayata kadar uzun bir zaman diliminde etkili ve gerekli olan bir beceridir. Bu bakımdan özellikle ilkokul ve ortaokul düzeyindeki öğrencilere duygularını, düşüncelerini ifade etme becerisinin kazandırılması gerekir.

Ortaokul 5 ve 8.sınıf öğrencilerinin cümle, paragraf ve metin oluşturma düzeyi üzerinde etkili olan değişkenler nelerdir? 
a. Öğrencilerin Yazılı Anlatım Düzeyini Belirlemek İçin Kullanılan Dereceli Puanlama Anahtarı'ndan (YAPA) aldığı toplam puanları ile cinsiyete göre anlamlı bir farklılık göstermekte midir?

b. Öğrencilerin YAPA' dan aldığı toplam puanlar ile sınıf düzeylerine göre anlamlı bir farklııık göstermekte midir?

c. Öğrencilerin YAPA'dan aldığı toplam puan ile annelerinin eğitim durumu arasında bir ilişki var mı?

d. Öğrencilerin YAPA'dan aldığı toplam puan ile babalarının eğitim durumu arasında bir ilişki var mı?

e Öğrencilerin YAPA'dan aldığı toplam puan ile sosyo-ekonomik düzeyleri arasında bir ilişki var mı?

f. Öğrencilerin YAPA'dan aldığı toplam puan ile evlerinde kitaplık bulunup bulunmama durumu arasında anlamlı bir farklılık var mıdır?

g. Öğrencilerin YAPA'dan aldığı toplam puan ile günlük tutup tutmama durumları arasında anlamlı bir farklılık var mıdır?

h. Öğrencilerin YAPA'dan aldığı toplam puan ile evlerine süreli yayın alma sıklığı arasında bir ilişki var mı?

I. Öğrencilerin YAPA'dan aldığı toplam puan ile evlerine okulunda kütüphane olup olmama arasında anlamlı bir farklılık var mıdır?

i. Öğrencilerin YAPA'dan aldığı toplam puan ile Yazarlık ve Yazma Becerileri dersi alıp almama durumu arasında anlamlı bir farklııı var mıdır?

j. Öğrencilerin YAPA'dan aldığı toplam puan ile düzenli olarak kitap okuyup okumama durumları arasında anlamlı bir farklılık var mıdır?

\section{Yöntem}

\section{Araştırmanın Modeli}

Bu çalışma, ortaokul öğrencilerinin cümle, paragraf ve metin oluşturma düzeyleri üzerinde etkili olan değişkenleri araştıran nicel bir araştırmadır.

Bu araştırmanın nicel boyutunda betimsel (survey) yöntemlerinden tarama yaklaşımı içinde yer alan ilişkisel tarama modeli kullanılmıştır. Tarama modelleri, geçmişte ya da halen var olan bir durumu var olduğu şekliyle betimlemeyi amaçlayan araştırma yaklaşımlarıdır (Karasar, 2005: 77). Betimleme / survey olarak da adlandırılan bu modeller araştırmaların ilk aşamasını oluşturur çünkü burada amaç araştırmaya konu olan olguları ve bu olgular arasındaki ilişkileri saptama, sınıflama ve kaydetmedir. (Yıldırım ve Şimşek, 2005: 56). Babbie (1990) "genellikle yapılandırılmıs anket ve yapılandırılmış görüşme yöntemlerinin kullanıldığı tarama yaklaşımlarının temel amacının 
örneklemden yola çıkarak evren hakkında genelleme yapmak" olduğunu belirtir. (Akt. Mertkan, 2012: $5)$.

\section{Örneklem/ Araştırma Grubu}

Araştırma Malatya il sınırları içinde yer alan 12 ortaokulda yürütülmüştür. Evreni daha iyi temsil edeceği düşüncesiyle farklı eğitim bölgelerindeki okullardan tabakalı örnekleme yoluyla (Sencer ve Sencer 1978, 466) öğrenciler araştırma örneklemine alınmıştır. Bu tekniğin özü, örneklemi seçmeden önce evreni bazı alt tabakalara ayırmak, sonra da örnekleri bu tabakalardan seçmektir.

Okullardan yine tesadüfî yöntemle iki sınıf seçilerek örneklem oluşturulmuştur. Malatya ili merkez ilçelerde öğrenim gören 5. sınıf öğrencilerinin 323, 8. sınıf öğrencilerinin 293 olmak üzere araştırmaya katılan öğrencilerin toplam sayıları 616'dır.

\section{Veri Toplama Araçları}

Araştırmanın verileri öğrencilerin yazılı anlatımlarından elde edilmiştir. Öğrencilerin yazı yazmalarını kolaylaştırmak için onlara on ayrı konu verilmiştir. Öğrencilerin bu konulardan birini seçerek yazı yazmaları istenmiştir.

Konu seçimi esnasında öğrencilerin her sınıf seviyesine göre edindikleri dil becerileri göz önünde bulundurulmuştur. Seçilen konuların öğrencilerin ilgi ve seviyelerine uygun, hayatlarıyla ilişkilendirebilecekleri, okuduklarını, gözlemlerini ve düşüncelerini yansıtabilecekleri türden olmasına dikkat edilmiştir. Türkçe eğitimi alanından 4 uzman görüşü alınarak konular oluşturulmuştur.

\section{Verilerin Toplanması}

Araştırmada elde edilen verileri toplamak için kullanılan Kişisel Bilgi Formu'nda, örnekleme dâhil olan ortaokul öğrencilerini tanımaya yönelik bilgileri elde etmeye yarayan maddeler yazıımıştır. Bu kapsamda, yapılan literatür taraması ışı̆ında tespit edilen ve yazılı anlatım beceri düzeyine etki edebilecek veriler tespit edilmiştir. Öğrencilere sorulacak soruların belirlenmesi için toplam beş uzmandan görüş alınmıştır. Uzmanlardan gelen eleştiriler sonrasında formda gerekli değişiklikler yapılarak kişisel bilgi formuna son hali verilmiştir. Kişisel Bilgi Formu; öğrencinin cinsiyeti, sınıfı, anne ve babanın öğrenim durumu, sosyo- ekonomik durumu, evde kitaplık olma durumu, günlük tutma durumu, okulda kütüphanenin olma durumu, eve süreli yayın alma sıklığı, düzenli olarak kitap okuma durumu, Yazarlık ve Yazma Becerileri dersi alma durumu gibi özellikleri öğrenmeye yönelik toplam 11 sorudan oluşan bir formdur.

\section{Verilerin Analizi}

Araştırmada elde edilen veriler nicel değerlendirme yöntemleri kullanılarak çözümlenmiştir. Nicel değerlendirme yoluyla öğrencilerin cümle, paragraf ve metin oluşturma düzeyleri sayısal 
Ortaokul Öğrencilerinin Cümle, Paragraf ve Metin Oluşturma Düzeyi Üzerinde Etkili Olan Değişkenler

verilerle ortaya konulmuştur. Araştırmada öğrencilerden alınan kompozisyonların değerlendirilmesinde Yazılı Anlatım Düzeyini Belirlemek İçin Kullanılan Dereceli Puanlama Anahtarı kullanılmıştır:

Bu dereceli puanlama anahtarının amacı çalışma grubunu oluşturan ortaokul öğrencilerinin yazılı anlatım düzeylerini belirlemektir. Elde edilen veriler, alan yazınındaki kurumsal bilgilerden faydalanılarak geliştirilen Yazılı Anlatım Düzeyini Belirlemek İçin Kullanılan Dereceli Puanlama Anahtarı (YAPA) (Ek-1) ile değerlendirilmiştir. YAPA'nın hazırlanma amacı öğrencilerin yazma düzeyi hakkında kullanışı ve güvenli bilgi elde edilmesini kolaylaştırmaktır.

Dereceli puanlama biçiminde oluşturulan ölçekte her ölçüt için öğrenciye 1, 2, 3 ve 4 puan verilmektedir. Her bir öğrencinin ölçekten alabileceği en düşük puan 16, en yüksek ise 64 'tür. Toplam puanın yüksek olmasının öğrencilerin cümle, paragraf ve metin düzeyinde beklenen nitelikleri yazılı anlatımlarda gösterdikleri, düşük olması da öğrencilerin cümle, paragraf ve metin düzeyinde beklenen nitelikleri yazılı anlatımlarda göstermedikleri şekilde yorumlanmaktadır.

Araştırmada kullanılan ölçme aracının geçerliliğini belirlemek için "içerik geçerliliği" ölçütlerinden biri olan uzman görüşüne başvurulmuştur (Karasar,1998; Çelik, 2000: 50). YAPA'da alan uzmanlarının görüşleri doğrultusunda bazı düzenlemeler yapılmıştır.

Araştırmada kullanılan YAPA'nın güvenilirliğini belirlemek için "gözlemciler arası uyum" yöntemine başvurulmuştur.

Örneklem içinden tesadüfî olarak seçilen 154 kompozisyon kâğıdı Türkçe öğretimi alnında uzman olan iki kişi ile ve araştırmacı tarafından ayrı ayrı değerlendirilmiştir. Daha sonra bu değerlendirmeler arasındaki ilişkiye Pearson Korelâsyon Analizi ile belirlenmiştir.

Puanlayııılar arasındaki tutarlılığı belirlemek üzere SPSS analiz programı yardımıyla küme içi korelasyon analizi (KiK) yapılmıştır. "Shrout ve Fleiss (1979) tarafından geliştirilen küme içi korelasyon analizi daha çok gözlemcilerin veya değerlendiricilerin yaptıkları puanlamanın tutarlılık güvenirliğini belirlemek için kullanılıı" (aktaran Şencan, 2005: 272). Shrout ve Fleiss küme içi korelasyon analizi için üç model önermektedir ve araştırmacılar kendi araştırmalarının amacına uygun olarak bu modellerden birini seçmektedirler. Bu araştırmada üç farklı puanlayıcı araştırma örnekleminde yer alan ve seçkisiz olarak belirlenen 154 veriyi değerlendirdikleri için Şencan'ın (2005) aktardığı modellerden KiK araştırma için uygun görülmüştür. Bu modelde "rastgele seçilen kişiler, çok sayıda farklı gözlemciler tarafından değerlendirilir. Çok sayıda gözlemcinin yaptığı değerlendirmelerin ortalamaları alınarak hesaplama yapılır. SPSS'te "Avarage Measure Intraclass Correlation" başlı̆ı altında gözlemcilerin ortalama değerlendirme güvenirlik katsayısı elde edilir" (Şencan, 2005: 275). 
Tablo 1. YAPA'nın değerlendirmeciler arasındaki karşılaştırmalı uyuşmanın güvenirliğine ilişkin küme içi korelasyon katsayısı

\begin{tabular}{lcc}
\hline & KiK & $p$ \\
\hline Küme içi korelasyon katsayısı & .92 & .01 \\
\hline Örneklem sayısı & 154 & \\
\hline
\end{tabular}

Tablo 1 incelendiğinde Kik.92 ve $\mathrm{p}$ değeri .01'dir. “Hesaplanan küme içi korelasyon katsayılarından $p<.40$ oranı zayıf; $p=.40$ ile .59 arasındaki oranları orta; $p=.60$ ile .74 arasındaki oranlar iyi ve $p>.75$ 'ten yüksek olan oranlar mükemmel olarak kabul edilebilir" (Şencan, 2005: 279). Bu değerlere göre incelendiğinde puanlayıcılar arasında mükemmel uyum olduğu belirtilebilir.

Araştırmaya katılan öğrencilerin YAPA'dan elde edilen toplam puanlarının dağııımlarının parametrik testlerin temel varsayımlarını karşılayıp karşılamadıklarını test etmek amacıyla veriler aritmetik ortalama, ortanca, mod, çarpıklık ve basıklık katsayıları bakımından incelenmiştir.

Tablo 2. YAPA'dan elde edilen toplam puanlara ilişkin betimsel değerler

\begin{tabular}{cccccc}
\hline Ölçek & $N$ & Ortanca & Mod & BK & ÇK \\
\hline 5. sınıf & 323 & 34,76 & 34,00 &, 51 &,- 30 \\
\hline 8. Sınıf & 293 & 39,81 & 38,00 &, 21 & $-1,00$ \\
\hline
\end{tabular}

Tablo 2 incelendiğinde çarpıklık ve basıklık katsayı değerlerinin ayırt edici dinleme alt ölçeği dışında +1 ile -1 arasında değiştiği görülmektedir. Ayrıca normallik testleri de yapılmış ve verilerin normal dağıldığı tespit edilmiştir. Bu nedenle alt problemler için yapılan analizlerde parametrik testler kullanılmıştır. Elde edilen veriler araştırmanın alt amaçları doğrultusunda parametrik testler olan tek yönlü ANOVA ve ilişkisiz (bağımsız) örneklemler için $t$-testi analizleri kullanılarak test edilmiştir.

Araştırmanın c, d, e,h alt problemlerini içeren değişkenlerle YAPA'dan elde edilen toplam puanlar arasında istatiksel olarak anlamlı bir farlılığın olup olmadığını test etmek amacıyla ilişkisiz örneklemler için tek yönlü varyans analizi (tek yönlü ANOVA) yapılmıştır. "ilişkisiz örneklemler için tek yönlü ANOVA, ikiden fazla bağımsız gruba ilişkin ortalamaların en az ikisi arasında istatistiksel olarak anlamlı bir fark olup olmadığını, 'ortalamalar arasında anlamlı bir fark yoktur' şeklindeki yokluk hipoteziyle test eder ve $\mathrm{F}$ değerinin anlamlılığı için hesaplanan $p$ değeri 0,05 'in üzerinde çıktığında bu hipotez kabul edilmiş olur" (Can, 2014:147).

Can (2014); Field (2009), Şencan, (2005) Tek yönlü ANOVA'nın güvenilir sonuçlar verebilmesi için örneklemin seçildiği evrenlere ait puanların dağılımın normal olması, grup varyanslarının homojen olması, bağımlı değişkenin eşit aralıklı veya oranlı ölçek verisi niteliğinde olması ve ölçüm yapılan her bir örneklemin birbirinden bağımsız olması gerektiğini belirtmektedir.

Büyüköztürk, Çokluk ve Köklü (2010:178), ANOVA'nın güçlü bir parametrik teknik olduğu için, mükemmel normal dağılıma, homojen evrenlere ve yansız olmayan örneklemlere sahip olmayan çalışmalarda kullanıldığını belirtmiştir. 
Araştırmanın $a, b, f, g, I, i, j$ alt problemlerini içeren değişkenlerle YAPA'dan elde edilen toplam puanlar arasında istatistiksel olarak anlamlı bir farlılığın olup olmadığını test etmek amacıyla ilişkisiz örneklemler için ilişkisiz (bağımsız) örneklemler için $t$-testi yapılmıştır.

\section{Bulgular}

Ortaokul 5 ve 8. Sınıf Öğrencilerinin YAPA'dan Aldıkları Toplam Puan ile Cinsiyetleri Arasındaki Ilişsi

Bu başııkta " Ortaokul 5 ve 8. sınıf öğrencilerinin YAPA'dan aldıkları toplam puan cinsiyete göre anlamlı bir farklılık göstermekte midir?" alt problemine cevap aranmaya çalışılmıştır. Bunu belirlemek için yapılan bağımsız grup t-Testi sonuçları Tablo 3'te yer almaktadır.

Tablo 3. YAPA'dan elde edilen toplam puanın ile öğrencinin cinsiyeti değişkenine göre farklılaşıp farklılaşmadığını belirlemek üzere yapılan bağımsız grup t testi sonuçları

\begin{tabular}{lccccccc}
\hline Cinsiyet & & $\mathrm{N}$ & $\overline{\mathrm{X}}$ & $\mathrm{S}$ & $\mathrm{t}$ & $\mathrm{sd}$ & $\mathrm{p}$ \\
\hline \multirow{2}{*}{ 5. Sınıf } & $\mathrm{K}$ Iz & 166 & 35,57 & 11,37 & 1,32 & 320,34 &, 185 \\
& Erkek & 157 & 33,90 & 11,25 & & & \\
\cline { 2 - 8 } 8. Sınıf & Kız & 148 & 43,48 & 13,74 & 4,61 & 290,82 & \multirow{2}{*}{001} \\
& Erkek & 145 & 36,06 & 13,79 & & & \\
\hline
\end{tabular}

${ }^{*} \mathrm{p} \leq .05$

Cinsiyetin, yazılı anlatım düzeylerini üzerinde anlamlı bir etkisi olup olmadığını ortaya koymak için yapılan ilişkisiz örneklemler için t testinde, 5.sınıflarda kız öğrencilerin ortalaması ( $\bar{X}=35,57)$, erkek öğrencilerin ortalaması $(\bar{X}=33,90)$ arasında anlamlı bir fark görülmemiştir $\left(\mathrm{t}_{(321)}=1,32, \mathrm{p}>0.05\right)$. Bu durumda 5.sınıf düzeyinde cinsiyetin yazılı anlatım düzeyinde anlamlı bir etkisinin olmadığı söylenebilir.

8. sınıflarda ise kız öğrencilerin ortalaması $(\bar{X}=43,48)$ erkek öğrencilerin ise $(\bar{X}=36,90)$ aralarında anlamlı bir fark vardır $\left(\mathrm{t}_{(291)}=4,61, \mathrm{p}<0.05\right)$. Bu durumda $8 . \operatorname{sın} ı$ düzeyinde cinsiyetin yazıı anlatım düzeyinde anlamlı bir etkisinin olduğu söylenebilir.

Araştırmaya katılan öğrencilerin yazma beceri düzeyleri cinsiyet değişkeni açısından 5 . sınıflarda anlamlı bir farklılık göstermemektedir 8.sınıflarda ise anlamlı bir farklılık göstermektedir.

Ortaokul 5 ve 8. Sını Öğrencilerinin YAPA'dan Aldıkları Toplam Puan ile Sınıf Düzeyleri Arasındaki ilişki

Bu başlıkta " Ortaokul 5 ve 8 . sınıf öğrencilerinin YAPA'dan aldıkları toplam puan sınıf düzeyine göre anlamlı bir farklılık göstermekte midir?" alt problemine cevap aranmaya çalışımıştır. Bunu belirlemek için yapılan bağımsız grup t-Testi sonuçları Tablo 4'te yer almaktadır.

Tablo 4. YAPA'dan elde edilen toplam puanın ile öğrencinin sınıf düzeyi değişkenine göre farklılaşıp farkılaş̧madığını belirlemek üzere yapılan bağımsız grup t testi sonuçları

\begin{tabular}{lcccccc}
\hline SINIF & $\mathrm{N}$ & $\overline{\mathrm{X}}$ & $\mathrm{S}$ & $\mathrm{t}$ & $\mathrm{sd}$ & $\mathrm{p}$ \\
\hline 5. Sinıf & 323 & 34,76 & 11,32 & $-4,837$ & 557,01 &, $001^{*}$ \\
8. Sinıf & 293 & 39,81 & 14,23 & & & \\
\hline
\end{tabular}

$* p \leq .05$ 
Sınıf düzeyinin, yazılı anlatım düzeylerini üzerinde anlamlı bir etkisi olup olmadığını ortaya koymak için yapılan ilişkisiz örneklemler için t testinde, 5.sınıflarda öğrencilerin ortalaması ( $\bar{X}=34,76)$, 8.sınıflarda öğrencilerin ortalaması ( $\bar{X}=39,81)$ arasında anlamlı bir fark vardır. $\left(t_{(514)}=4,837, p<0.05\right)$ durumunun yazılı anlatım düzeyi üzerinde anlamlı etkisinin olduğunu göstermektedir.

Bu durumda sınıf düzeylerinin yazılı anlatım düzeyinde anlamlı bir etkisinin olduğu söylenebilir. 8.sınıflarda ise kız öğrencilerin ortalaması $(\bar{X}=34,76)$ erkek öğrencilerin ise $(\bar{X}=39,81)$ aralarında anlamlı bir fark vardır $\left(\mathrm{t}_{(614)}=4,83, \mathrm{p}<0.05\right)$. Yapılan çalışmada 8 .sınıf öğrencilerinin yazılı anlatım düzeylerinin 5. Sınıf öğrencilerinin yazılı anlatım düzeylerine göre anlamlı bir farklılık gösterdiği tespit edilmiştir.

Ortaokul 5 ve 8. Sınıf Öğrencilerinin YAPA'dan Aldıkları Toplam Puan ile Annelerinin Eğitim Düzeyleri Arasındaki ilişki

Bu başlıkta "Öğrencilerin YAPA' dan aldığı toplam puan ile annelerinin eğitim durumu arasında bir ilişki var mı?" alt problemine cevap aranmaya çalışımıştır. Bunu belirlemek için yapılan tek yönlü varyans analizinin sonuçları Tablo 5 ve Tablo 6'da yer almaktadır.

Tablo 5. 5. sınıf öğrencilerinin yapa'dan elde edilen toplam puan ile annelerinin eğitim düzeyi arasındaki ilişkiyi gösteren tek yönlü anova sonuçları

\begin{tabular}{lcccccc}
\hline $\begin{array}{l}\text { Varyansın } \\
\text { Kaynağı }\end{array}$ & $\begin{array}{c}\text { Kareler } \\
\text { Toplamı }\end{array}$ & sd & $\begin{array}{c}\text { Kareler } \\
\text { Ortalaması }\end{array}$ & $f$ & $p$ & Anlamlı Fark \\
\hline Gruplar arası & 4214,406 & 5 & 842,881 & 7,202 &, $000^{*}$ & $\begin{array}{c}\text { Üniversite>0kur } \\
\text { yazar değil } \\
\text { Üniversite>ilkokul }\end{array}$ \\
Gruplar içi & 37097,711 & 317 & 117,027 & & $\begin{array}{c}\text { Üniversite>ortaokul } \\
\text { Lise>ortaokul }\end{array}$ \\
Toplam & 41312,118 & 322 & & & & \\
\hline
\end{tabular}

$* p \leq .05$

Tablo 5 incelendiğinde yapılan analizler sonucunda $\left(\bar{X}_{\text {okur yazar değil }}=31,60\right),\left(\bar{X}_{\text {ilkokul }}=33,92\right)$ ve $\left(\bar{X}_{\text {ortaokul }}=31,16\right),\left(\bar{X}_{\text {lise }}=37,59\right),\left(\bar{X}_{\text {üniversite }}=41,52\right),\left(\bar{X}_{\text {yüksek lisans }}=35,16\right)$, gruplarının en az ikisi arasında istatistiksel olarak anlamlı fark gözlenmiştir. $\left[F_{(5-317)}=7,20 \mathrm{p}<0.00\right]$.Test sonucu hesaplanan etki büyüklüğü $\left(\eta^{2}=0,10\right)$ Cohen'in (1988) ifadesiyle bu farkın orta düzeyde olduğunu göstermektedir. Cohen 0,01 değeri küçük etki, 0,06 değeri orta düzey etki ve 0,14 'ü büyük etki değeri olarak sınıflandırmaktadır (aktaran Pallant, 2015/2016:282). Yapılan Tukey çoklu karşılaştırma testi sonucunda, anlamlı farkın annesi üniversite mezunu olan öğrencilerle ile annesi okuryazar olmayan öğrenciler arasında, annesi üniversite mezunu olan öğrencilerle annesi ilkokul mezunu olan öğrenciler arasında, annesi üniversite mezunu olan öğrencilerle annesi ortaokul mezunu olan öğrenciler arasında ve annesi lise mezunu olan öğrencilerle annesi ortaokul mezunu olan öğrenciler arasında olduğu görülmüştür. 
Ortaokul Öğrencilerinin Cümle, Paragraf ve Metin Oluşturma Düzeyi Üzerinde Etkili Olan Değişkenler

Tablo 6. 8. sınıf öğrencilerinin yapa'dan elde edilen toplam puan ile annelerinin eğitim düzeyi arasındaki ilişkiyi gösteren tek yönlü anova sonuçları

\begin{tabular}{|c|c|c|c|c|c|c|}
\hline $\begin{array}{l}\text { Varyansın } \\
\text { Kaynağı } \\
\end{array}$ & $\begin{array}{l}\text { Kareler } \\
\text { Toplamı }\end{array}$ & sd & $\begin{array}{c}\text { Kareler } \\
\text { Ortalaması } \\
\end{array}$ & $f$ & $\mathrm{p}$ & Anlamlı Fark \\
\hline Gruplar arası & 5576,921 & 4 & 842,881 & 7,48 & ,000* & $\begin{array}{c}\text { Üniversite>okur } \\
\text { yazar değil } \\
\text { Üniversite>ilkokul }\end{array}$ \\
\hline Gruplar içi & 53623,755 & 288 & 117,027 & & & $\begin{array}{c}\text { Üniversite>ortaokul } \\
\text { Lise>ilkokul }\end{array}$ \\
\hline Toplam & 59200,676 & 292 & & & & \\
\hline
\end{tabular}

${ }^{*} p \leq .05$

Tablo 6 incelendiğinde yapılan analizler sonucunda $\left(\bar{X}_{\text {okur yazar değil }}=36,66\right),\left(\bar{X}_{\text {ikokul }}=36,21\right)$ ve $\left(\bar{X}_{\text {ortaokul }}=38,85\right),\left(\bar{X}_{\text {lise }}=43,04\right),\left(\bar{X}_{\text {üniversite }}=52,09\right)$, gruplarının en az ikisi arasında istatistiksel olarak anlamlı fark gözlenmiştir. $\left[F_{(4-288)}=7,48 p<0.00\right]$.Test sonucu hesaplanan etki büyüklüğü $\left(\eta^{2}=0,09\right)$ Cohen'in (1988) ifadesiyle bu farkın orta düzeyde olduğunu göstermektedir. Cohen 0,01 değeri küçük etki, 0,06 değeri orta düzey etki ve 0,14 'ü büyük etki değeri olarak sınıflandırmaktadır (aktaran Pallant, 2015/2016:282).

Yapılan Tukey çoklu karşılaştırma testi sonucunda, anlamlı farkın annesi üniversite mezunu olan öğrencilerle ile annesi okuryazar olmayan öğrenciler arasında, annesi üniversite mezunu olan öğrencilerle annesi ilkokul mezunu olan öğrenciler arasında, annesi üniversite mezunu olan öğrencilerle annesi ortaokul mezunu olan öğrenciler arasında ve annesi lise mezunu olan öğrencilerle annesi ilkokul mezunu olan öğrenciler arasında olduğu görülmüştür.

Ortaokul 5 ve 8. Sınıf Öğrencilerinin YAPA'dan Aldıkları Toplam Puan ile Babalarının Eğitim Düzeyleri Arasındaki ilişki

Bu başlıkta " Öğrencilerin YAPA'dan aldığı toplam puan ile babalarının eğitim durumu arasında bir ilişki var mı?” alt problemine cevap aranmaya çalışılmıştır. Bunu belirlemek için yapılan tek yönlü varyans analizinin sonuçları Tablo 7 ve Tablo 8'de yer almaktadır.

Tablo 7. 5. sınıf öğrencilerinin yapa'dan elde edilen toplam puan ile babalarının eğitim düzeyi arasındaki ilişkiyi gösteren tek yönlü anova sonuçları

\begin{tabular}{lcccccc}
\hline $\begin{array}{l}\text { Varyansın } \\
\text { Kaynağı }\end{array}$ & $\begin{array}{c}\text { Kareler } \\
\text { Toplamı }\end{array}$ & sd & $\begin{array}{c}\text { Kareler } \\
\text { Ortalaması }\end{array}$ & $f$ & $\mathrm{p}$ & Anlamlı Fark \\
\hline Gruplar arası & 2388,404 & 4 & 597,101 & 4,878 & $0,001^{*}$ & Üniversite>ilkokul \\
Gruplar içi & 38923,714 & 318 & 122,402 & & & Üniversite>ortaokul \\
Toplam & 41312,118 & 322 & & & & \\
\hline
\end{tabular}

$* p \leq .05$

Tablo 7 incelendiğinde yapılan analizler sonucunda $\left(\bar{X}_{\text {ikokul }}=32,77\right)$ ve $\left(\bar{X}_{\text {ortaokul }}=32,03\right),\left(\bar{X}_{\text {lise }}\right.$ $=34,52),\left(\bar{X}_{\text {üniversite }}=38,8\right),\left(\bar{X}_{\text {yüksek lisans }}=38,0\right)$, gruplarının en az ikisi arasında istatistiksel olarak anlamlı fark gözlenmiştir. $\left[F_{(4-318)}=4,878 p<0.00\right]$.Test sonucu hesaplanan etki büyüklüğü $\left(\eta^{2}=0,06\right)$ Cohen'in (1988) ifadesiyle bu farkın orta düzeyde olduğunu göstermektedir. Cohen 0,01 değeri küçük etki, 0,06 
değeri orta düzey etki ve 0,14 'ü büyük etki değeri olarak sınıflandırmaktadır (aktaran Pallant, 2015/2016:282).

Yapılan Tukey çoklu karşılaştırma testi sonucunda, anlamlı farkın babası üniversite mezunu olan öğrencilerle ilkokul mezunu olan öğrenciler arasında, babası üniversite mezunu olan öğrencilerle ortaokul mezunu olan öğrenciler arasında olduğu görülmüştür.

Tablo 8. 8. sınıf öğrencilerinin yapa'dan elde edilen toplam puan ile babalarının eğitim düzeyi arasındaki ilişkiyi gösteren tek yönlü anova sonuçları

\begin{tabular}{|c|c|c|c|c|c|c|}
\hline $\begin{array}{l}\text { Varyansın } \\
\text { Kaynağı } \\
\end{array}$ & $\begin{array}{l}\text { Kareler } \\
\text { Toplamı }\end{array}$ & sd & $\begin{array}{c}\text { Kareler } \\
\text { Ortalaması }\end{array}$ & $f$ & $\mathrm{p}$ & Anlamlı Fark \\
\hline Gruplar arası & 7320,106 & 4 & 1830,027 & 10,159 & $0,000 *$ & $\begin{array}{c}\text { Lise>ilkokul } \\
\text { Üniversite>ilkokul }\end{array}$ \\
\hline Gruplar içi & 51880,570 & 288 & 180,141 & & & $\begin{array}{l}\text { Üniversite>ortaokul } \\
\text { Üniversite>lise }\end{array}$ \\
\hline Toplam & 59200,676 & 292 & & & & \\
\hline
\end{tabular}

$* p \leq .05$

Tablo 8 incelendiğinde yapılan analizler sonucunda, $\left(\bar{X}_{\text {ikokul }}=34,37\right),\left(\bar{X}_{\text {ortaokul }}=36,80\right),\left(\bar{X}_{\text {lise }}\right.$ $=40,63)$, ( $\left.\bar{X}_{\text {universite }}=49,74\right)$, $\left(\bar{X}_{\text {yüksek lisans }}=41,83\right)$, gruplarının en az ikisi arasında istatistiksel olarak anlamlı fark gözlenmiştir. $\left[F_{(4-288)}=10,15 p<0.00\right]$.Test sonucu hesaplanan etki büyüklüğü $\left(\eta^{2}=0,14\right)$ Cohen'in (1988) ifadesiyle bu farkın büyük düzeyde olduğunu göstermektedir. Cohen 0,01 değeri küçük etki, 0,06 değeri orta düzey etki ve 0,14 ‘ü büyük etki değeri olarak sınıflandırmaktadır (aktaran Pallant, 2015/2016:282).

Yapılan Tukey çoklu karşılaştırma testi sonucunda, anlamlı farkın babası lise mezunu olan öğrencilerle ilkokul mezunu olan öğrenciler arasında, babası üniversite mezunu ile ilkokul mezunu olan öğrenciler arasında, babası üniversite mezunu ile ortaokul mezunu olan öğrenciler arasında, babası üniversite mezunu olan öğrencilerle lise mezunu olan öğrenciler arasında olduğu görülmüştür.

Ortaokul 5 ve 8. Sınıf Öğrencilerinin YAPA'dan Aldığı Toplam Puan ile Sosyo-Ekonomik Düzeyleri Arasındaki ilişki

Bu başııta “Öğrencilerin YAPA'dan aldığı toplam puan ile sosyo-ekonomik düzeyleri arasında bir ilişki var mı?” alt problemine cevap aranmaya çalışımıştır. Bunu belirlemek için yapılan tek yönlü varyans analizinin sonuçları Tablo 9 ve Tablo 10'da yer almaktadır.

Tablo 9. 5. sınıf öğrencilerinin yapa'dan elde edilen toplam puan ile ailenin gelir düzeyi arasındaki ilişkiyi gösteren tek yönlü anova sonuçları

\begin{tabular}{lcccccc}
\hline $\begin{array}{l}\text { Varyansın } \\
\text { Kaynağı }\end{array}$ & $\begin{array}{c}\text { Kareler } \\
\text { Toplamı }\end{array}$ & sd & $\begin{array}{c}\text { Kareler } \\
\text { Ortalaması }\end{array}$ & $f$ & $\mathrm{p}$ & Anlamlı Fark \\
\hline Gruplar arası & 1460,941 & 3 & 486,980 & 3,898 & $0,001^{*}$ & $\begin{array}{c}\text { Üst>orta } \\
\text { Üst>alt } \\
\text { Gruplar içi }\end{array}$ \\
$\begin{array}{l}39851,177 \\
\text { Toplam }\end{array}$ & 319 & 124,925 & & & Orta >alt \\
\hline
\end{tabular}

${ }^{*} p \leq .05$ 
Ortaokul Öğrencilerinin Cümle, Paragraf ve Metin Oluşturma Düzeyi Üzerinde Etkili Olan Değişkenler

Tablo 9 incelendiğinde yapılan analizler sonucunda alt grup ( $\bar{X}$ alt $=33,08)$, ( $\bar{X}$ orta $=34,05)$ ve (Ẍüst =40,84), gruplarının en az ikisi arasında istatistiksel olarak anlamlı fark gözlenmiştir. [F(2$320)=6,745, p<0.05]$.Test sonucu hesaplanan etki büyüklüğü $\left(\eta^{2}=0,04\right)$ Cohen'in (1988) ifadesiyle bu farkın orta düzeyde olduğunu göstermektedir. Cohen 0,01 değeri küçük etki, 0,06 değeri orta düzey etki ve 0,14 ‘ü büyük etki değeri olarak sınıflandırmaktadır (aktaran Pallant, 2015/2016:282).

Yapılan Tukey çoklu karşılaştırma testi sonucunda, üst düzey gelirli ailelerin çocukları ile orta gelirli ailelerin çocuklarının yazma beceri düzeyleri puanları arasında anlamlı bir farklılaşmanın olduğu görülmüştür. Üst düzey gelirli ailelerin çocuklarıyla ile alt düzey gelirli ailelerin çocuklarının toplam puanları arasında da benzer şekilde anlamlı bir farklılaşma söz konusudur.

Tablo 10. 8. Sınıf Öğrencilerinin YAPA'dan Aldığı Toplam Puan ile Ailenin Gelir Düzeyi Arasındaki ilişskiyi Gösteren Tek Yönlü ANOVA Sonuçları

\begin{tabular}{lcccccc}
\hline $\begin{array}{l}\text { Varyansın } \\
\text { Kaynağı }\end{array}$ & $\begin{array}{c}\text { Kareler } \\
\text { Toplamı }\end{array}$ & sd & $\begin{array}{c}\text { Kareler } \\
\text { Ortalaması }\end{array}$ & $f$ & $p$ & Anlamlı Fark \\
\hline Gruplar arası & 1753,356 & 2 & 876,678 & 4,42 & $0,010^{*}$ & orta>alt \\
Gruplar içi & 41312,118 & 290 & 198,094 & & & üst>alt \\
Toplam & 59200,676 & 292 & & & & \\
\hline
\end{tabular}

$* p \leq .05$

Tablo 10 incelendiğinde yapılan analizler sonucunda alt grup $\left(\bar{X}_{\text {alt }}=28,76\right),\left(\bar{X}_{\text {orta }}=40,49\right)$ ve $\left(\bar{X}_{\text {üst }}=38,28\right)$, gruplarının en az ikisi arasında istatistiksel olarak anlamlı fark gözlenmiştir. $\left[F_{(2-292)}=4,42\right.$, $p<0.05]$.Test sonucu hesaplanan etki büyüklüğü $\left(\eta^{2}=0,03\right)$ Cohen'in (1988) ifadesiyle bu farkın orta düzeyde olduğunu göstermektedir. Cohen 0,01 değeri küçük etki, 0,06 değeri orta düzey etki ve 0,14 ‘ü büyük etki değeri olarak sınıflandırmaktadır (aktaran Pallant, 2015/2016:282).

Yapılan Tukey çoklu karşılaştırma testi sonucunda, anlamlı farkın orta düzey gelir grubuyla alt düzey gelir grubu arasında, üst düzey gelir grubuyla alt düzey gelir grubu arasında olduğu görülmüştür.

Ortaokul 5 ve 8. Sınıf Öğrencilerinin YAPA'dan Aldığı Toplam Puan ile Evlerinde Kitaplık Olma Durumları Arasındaki Iliş̧i

Bu başlıkta “Öğrencilerin YAPA'dan aldığı toplam puan ile evlerinde kitaplık bulunup bulunmama durumu arasında anlamlı bir farklıık var mıdır ?" alt problemine cevap aranmaya çalışılmıştır. Bunu belirlemek için yapılan bağımsız grup t-Testi sonuçları Tablo 11'de yer almaktadır.

Tablo 11. YAPA'dan elde edilen toplam puanın ile öğrencinin evinde kitaplık olma değişkenine göre farklılaşıp farklılaşmadığını belirlemek üzere yapılan bağımsız grup t testi sonuçları

\begin{tabular}{llcccccc}
\hline \multicolumn{2}{l}{ Evde Kitaplık Bulunma } & $\mathrm{N}$ & $\overline{\mathrm{X}}$ & $\mathrm{S}$ & $\mathrm{t}$ & $\mathrm{sd}$ & $\mathrm{p}$ \\
\hline \multirow{2}{*}{ 5. sınıf } & Evet & 218 & 36,07 & 11,10 & 3,017 & 201,353 &, $003 *$ \\
& Hayır & 105 & 32,03 & 11,35 & & & \\
\cline { 2 - 7 } 8. sinıf & Evet & 212 & 40,83 & 14,47 & 2,064 & 156,283 &, $041 *$ \\
& Hayır & 81 & 37,14 & 13,32 & & & \\
\hline
\end{tabular}


Evinde kitaplık bulunmanın, yazılı anlatım düzeylerini üzerinde anlamlı bir etkisi olup olmadığını ortaya koymak için yapılan ilişkisiz örneklemler için t testinde, 5.sınıflarda evde kitaplık bulunan kız öğrencilerin ortalaması ( $\bar{X}=36,07)$, evinde kitaplık bulunmayan öğrencilerin ortalaması $(\bar{X}=32,03)$ arasında anlamlı bir fark vardır. $\left(t_{(321)}=3,017, p<0.05\right)$. Bu durumda 5.sınıf düzeyinde evde kitaplık olma durumunun yazııı anlatım düzeyi üzerinde anlamlı etkisinin olduğunu göstermektedir.

8.sınıflarda evde kitaplık bulunan kız öğrencilerin ortalaması $(\bar{X}=40,83)$, erkek öğrencilerin ortalaması $(\bar{X}=37,14)$ arasında anlamlı bir fark yoktur. $\left(t_{(291)}=2,064, p<0.05\right)$. Bu durumda 5.sınıf düzeyinde evde kitaplık olma durumunun yazılı anlatım düzeyi üzerinde anlamlı etkisinin olduğu görülürken 8.sınıf düzeyinde evde kitaplık olma durumunun yazılı anlatım düzeyi üzerinde anlamlı etkisinin olmadığı tespit edilmiştir.

Ortaokul 5 ve 8. Sınıf Öğrencilerinin YAPA'dan Aldığı Toplam Puan ile Günlük Tutma Durumları Arasındaki ilişki

Bu başlıkta “Öğrencilerin YAPA'dan aldığı toplam puan ile günlük tutma durumları arasında anlamlı bir farklılık var mıdır ?" alt problemine cevap aranmaya çalışılmıştır. Bunu belirlemek için yapılan bağımsız grup t-Testi sonuçları Tablo 12'de yer almaktadır.

Tablo 12. YAPA'dan elde edilen toplam puanın ile öğrencinin günlük tutma değişkenine göre farklılaşıp farklılaşmadığını belirlemek üzere yapılan bağımsız grup t testi sonuçları

\begin{tabular}{llcccccc}
\hline \multicolumn{2}{l}{ Günlük tutma } & $\mathrm{N}$ & $\overline{\mathrm{X}}$ & $\mathrm{S}$ & $\mathrm{t}$ & $\mathrm{sd}$ & $\mathrm{p}$ \\
\hline \multirow{2}{*}{ 5. sınıf } & Evet & 122 & 34,28 & 12,04 & 0,576 & 146,019 &, 324 \\
& Hayır & 201 & 35,05 & 10,88 & & & \\
\cline { 2 - 8 } 8. sınıf & Evet & 43 & 43,65 & 14,25 & 1,91 & 57,19 &, 061 \\
& Hayır & 250 & 39,15 & 14,16 & & & \\
\hline
\end{tabular}

Günlük tutmanın, yazııı anlatım düzeylerini üzerinde anlamlı bir etkisi olup olmadığını ortaya koymak için yapılan ilişkisiz örneklemler için t testinde, 5.sınıflarda evde kitaplık bulunan öğrencilerin ortalaması $(\bar{X}=34,28)$, evinde kitaplık bulunmayanların $(\bar{X}=35,05)$ arasında anlamlı bir fark yoktur $\left(t_{(321)}=0,576, p>0.05\right)$. Bu durumda 5.sınıf düzeyinde günlük tutma durumunun yazılı anlatım düzeyi üzerinde anlamlı etkisinin olmadığını göstermektedir.

8.sınıflarda günlük tutan öğrencilerin ortalaması $(\bar{X}=43,65)$, günlük tutmayan öğrencilerin ortalaması $(\bar{X}=39,15)$ arasında anlamlı bir fark yoktur. $\left(t_{(291)}=1,91, p>0.05\right)$. Bu durumda 8.sınıf düzeyinde günlük tutma durumunun yazııı anlatım düzeyi üzerinde anlamlı etkisinin olmadığını göstermektedir. 
Ortaokul 5 ve 8. Sınıf Öğrencilerinin YAPA'dan Aldıkları Puan ile Evlerine Süreli Yayın Alma Sıkıkları Arasındaki ilişki

Bu başlıkta “Öğrencilerin YAPA'dan aldığı toplam puan ile evlerinde kitaplık bulunup bulunmama durumu arasında anlamlı bir farklılık var mıdır?" alt problemine cevap aranmaya çalışılmıştır. Bunu belirlemek için yapılan tek yönlü varyans analizinin sonuçları Tablo 13 ve Tablo 14 'te yer almaktadır.

Tablo 13. 5. sınıf öğrencilerinin yapa'dan aldığı toplam puan ile eve süreli yayın alma sıklığı arasındaki ilişkiyi gösteren tek yönlü anova sonuçları

\begin{tabular}{lcccccc}
\hline $\begin{array}{l}\text { Varyansın } \\
\text { Kaynağı }\end{array}$ & $\begin{array}{c}\text { Kareler } \\
\text { Toplamı }\end{array}$ & sd & $\begin{array}{c}\text { Kareler } \\
\text { Ortalaması }\end{array}$ & $\mathrm{f}$ & $\mathrm{p}$ & Anlamlı Fark \\
\hline Gruplar arası & 1460,941 & 3 & 486,980 & 3,898 &, 009 & Haftada bir>hiç \\
Gruplar içi & 39851,177 & 319 & 124,925 & & & \\
Toplam & 41312,118 & 322 & & & & \\
\hline
\end{tabular}

$* p \leq .05$

Tablo 13 incelendiğinde yapılan analizler sonucunda evine hiç süreli yayın almayan $\left(\mathbb{X}_{\text {hị̧ }}\right.$ $=32,75)$, evine ayda bir yayın alan $\left(\bar{X}_{\text {aydabir }}=37,03\right)$, evine haftada bir yayın alan $\left(\bar{X}_{\text {haftadabir }}=37,24\right)$, evine her gün yayın alan $\left(\left(\bar{X}_{\text {hergün }}=34,20\right)\right.$ gruplarının en az ikisi arasında istatistiksel olarak anlamlı fark gözlenmiştir. $\left[F_{(3-319)}=3,89, p<0.05\right]$.Test sonucu hesaplanan etki büyüklüğü $\left(\eta^{2}=0,03\right)$ Cohen'in (1988) ifadesiyle bu farkın orta düzeyde olduğunu göstermektedir. Cohen 0,01 değeri küçük etki, 0,06 değeri orta düzey etki ve 0,14 'ü büyük etki değeri olarak sınıflandırmaktadır (aktaran Pallant, 2015/2016:282). Yapılan Tukey çoklu karşılaştırma testi sonucunda, anlamlı farkın evine haftada bir yayın alan öğrencilerle evine hiç yayın almayan öğrenciler arasında olduğu görülmüştür.

Tablo 14. 8. sınıf öğrencilerinin yapa'dan aldığı toplam puan ile eve süreli yayın alma sıklığı arasındaki ilişkiyi gösteren tek yönlü anova sonuçları

\begin{tabular}{lcccccc}
\hline $\begin{array}{l}\text { Varyansın } \\
\text { Kaynağı }\end{array}$ & $\begin{array}{c}\text { Kareler } \\
\text { Toplamı }\end{array}$ & sd & $\begin{array}{c}\text { Kareler } \\
\text { Ortalaması }\end{array}$ & $f$ & $\mathrm{p}$ & Anlamlı Fark \\
\hline Gruplar arası & 2964,026 & 3 & 486,980 & 5,077 & 0,02 & $\begin{array}{c}\text { ayda bir>hiç } \\
\text { her gün>ayda bir }\end{array}$ \\
$\begin{array}{l}\text { Gruplar içi } \\
\text { Toplam }\end{array}$ & 56236,650 & 289 & 124,925 & & & \\
\hline
\end{tabular}

$* p \leq .05$

Tablo 14 incelendiğinde yapılan analizler sonucunda evine hiç süreli yayın almayan $\left(\bar{X}_{\text {hiç }}\right.$ $=37,69)$, evine ayda bir yayın alan $\left(\bar{X}_{\text {aydabir }}=43,57\right)$, evine haftada bir yayın alan $\left(\bar{X}_{\text {haftadabir }}=41,18\right)$, evine her gün yayın alan $\left(\left(\bar{X}_{\text {hergün }}=32,76\right)\right.$ gruplarının en az ikisi arasında istatistiksel olarak anlamlı fark gözlenmiştir. $\left[F_{(3-289)}=3,89, p<0.05\right]$.Test sonucu hesaplanan etki büyüklüğü $\left(\eta^{2}=0,05\right)$ Cohen'in $(1988)$ ifadesiyle bu farkın orta düzeyde olduğunu göstermektedir. Cohen 0,01 değeri küçük etki, 0,06 değeri orta düzey etki ve 0,14 'ü büyük etki değeri olarak sınıflandırmaktadır (aktaran Pallant, 2015/2016:282). Yapılan Tukey çoklu karşılaştırma testi sonucunda, anlamlı farkın evine ayda bir 
yayın alan öğrencilerle evine hiç yayın almayan öğrenciler arasında, evine her gün yayın alan öğrencilerle evine ayda bir yayın alan öğrenciler arasında olduğu görülmüştür.

Öğrencilerin yazılı anlatım düzeylerinin eve süreli yayın alma sıklığına göre farklılık gösterir. Buna göre anlamlı farkın evine ayda bir yayın alan öğrencilerle evine hiç yayın almayan öğrenciler arasında, evine her gün yayın alan öğrencilerle evine ayda bir yayın alan öğrenciler arasında olduğu tespit edilmiştir. Evlerine süreli yayın alınan öğrencilerin yazma düzeyleri evine hiç süreli yayın girmeyenlere göre anlamlı bir şekilde daha yüksek olduğu tespit edilmiştir.

Ortaokul 5 ve 8. Sınıf Öğrencilerinin YAPA'dan Aldığı Toplam Puan ile Okullarında Kütüphane Bulunma Durumları Arasındaki ilişki

Bu başıkta “Öğrencilerin YAPA'dan aldığı toplam puan ile okullarında kitaplık bulunup bulunmama durumu arasında anlamlı bir farklılık var mıdır ?" alt problemine cevap aranmaya çalışımıştır. Bunu belirlemek için yapılan bağımsız grup t-Testi sonuçları Tablo 15’te yer almaktadır.

Tablo 15. Öğrencilerin yapa'dan aldığı toplam puanın okulunda kütüphane bulunma değişkenine göre farklılaşıp farklılaşmadığını belirlemek üzere yapılan bağımsız grup t testi sonuçları

\begin{tabular}{llcccccc}
\hline \multicolumn{2}{l}{ Okulda kütüphane bulunma } & $\mathrm{N}$ & $\overline{\mathrm{X}}$ & $\mathrm{S}$ & $\mathrm{t}$ & $\mathrm{sd}$ & $\mathrm{p}$ \\
\hline \multirow{2}{*}{ 5. sınıf } & Evet & 245 & 35,09 & 11,65 &, 990 & 146,01 &, 324 \\
& Hayır & 78 & 39,16 & 13,95 & & & \\
\hline \multirow{2}{*}{ 8. sınıf } & Evet & 227 & 43,65 & 14,25 & $-1,391$ & 99,701 &, 167 \\
& Hayır & 66 & 39,16 & 15,06 & & & \\
\hline
\end{tabular}

Okulunda kütüphane bulunmanın, yazılı anlatım düzeylerini üzerinde anlamlı bir etkisi olup olmadığını ortaya koymak için yapılan ilişkisiz örneklemler için t testinde, 5.sınıflarda okulunda kitaplık bulunan öğrencilerin ortalaması $(\bar{X}=35,09)$, evinde kitaplık bulunmayanların $(\bar{X}=39,16)$ arasında anlamlı bir fark yoktur $\left(\mathrm{t}_{(321)}=0,576, \mathrm{p}<0.05\right)$. Bu durumda 5 .sınıf düzeyinde okulunda kütüphane bulunma durumunun yazılı anlatım düzeyi üzerinde anlamlı etkisinin olmadığını göstermektedir.

8.sınıf öğrencilerinden okulunda kütüphane bulunanların ortalaması $(\bar{X}=43,65)$, okulunda kütüphane bulunmayan öğrencilerin ortalaması $(\bar{X}=39,15)$ arasında anlamlı bir fark yoktur $\left(t_{(291)}=1,91\right.$ ,p>0.05). Bu durumda 8.sınıf düzeyinde okulunda kütüphane bulunma durumunun yazılı anlatım düzeyi üzerinde anlamlı etkisinin olmadığını göstermektedir.

Ortaokul 5 ve 8. Sınıf Öğrencilerinin YAPA'dan Aldığı Toplam Puan ile Yazarlık ve Yazma Becerileri Dersi Alma Durumu Arasındaki ilişki

Bu başlıkta “Öğrencilerin YAPA'dan aldığı toplam puan ile Yazarlık ve Yazma Becerileri dersi alıp almama durumu arasında anlamlı bir farklılık var mıdır?" alt problemine cevap aranmaya çalışılmıştır. Bunu belirlemek için yapılan bağımsız grup t-Testi sonuçları Tablo 16 'da yer almaktadır. 
Ortaokul Öğrencilerinin Cümle, Paragraf ve Metin Oluşturma Düzeyi Üzerinde Etkili Olan Değişkenler

Tablo 16. YAPA'dan alınan toplam puanın öğrencinin yazarlık ve yazma becerileri dersi alma durumuna göre farklılaşıp farklılaşmadığını belirlemek üzere yapılan bağımsız grup t testi sonuçları

\begin{tabular}{llcccccc}
\hline \multicolumn{2}{l}{ Yazarlık ve Yazma Becerileri } & $\mathrm{N}$ & $\overline{\mathrm{X}}$ & $\mathrm{S}$ & $\mathrm{t}$ & $\mathrm{sd}$ & $\mathrm{p}$ \\
\hline \multirow{2}{*}{ 5. sınıf } & Evet & 76 & 34,52 & 12,10 &,-200 & 116,49 & \multirow{2}{*}{, $842^{*}$} \\
& Hayır & 247 & 34,83 & 11,10 & & & \\
\cline { 2 - 6 } 8. sinıf & Evet & 72 & 36,95 & 12,97 & $-2,085$ & 133,726 &, $039 *$ \\
& Hayır & 221 & 40,74 & 14,53 & & & \\
\hline
\end{tabular}

$* p \leq .05$

Yazarlık ve Yazma Becerileri dersi almanın, yazılı anlatım düzeylerini üzerinde anlamlı bir etkisi olup olmadığını ortaya koymak için yapılan ilişkisiz örneklemler için t testinde, 5.sınıflarda Yazarlık ve Yazma Becerileri dersi alan öğrencilerin ortalaması ( $\bar{X}=34,52)$, Yazarlık ve Yazma Becerileri dersi almayan öğrenciler $(\bar{X}=34,83)$ arasında anlamlı bir fark yoktur $\left(t_{(321)}=0,200, p>0.05\right)$. Bu durumda 5.sınıf düzeyinde Yazarlık ve Yazma Becerileri dersi alma durumunun yazılı anlatım düzeyi üzerinde anlamlı etkisinin olmadığını göstermektedir.

8.sınıflarda Yazarlık ve Yazma Becerileri dersi alan öğrencilerin ortalaması ( $\bar{X}=36,95)$, Yazarlık ve Yazma Becerileri dersi almayan öğrencilerin ortalaması $(\bar{X}=40,74)$ arasında anlamlı bir fark yoktur $\left(t_{(291)}=2,085, p>0.05\right)$. Bu durumda 8.sınıf düzeyinde Yazarlık ve Yazma Becerileri dersi alma durumunun yazılı anlatım düzeyi üzerinde anlamlı etkisinin olmadığını göstermektedir.

Ortaokul 5 ve 8. Sınıf Öğrencilerinin YAPA'dan Aldığı Toplam Puan ile Öğrencilerin Düzenli Olarak Kitap Okuma Durumları Arasındaki IIlişki

Bu başlıkta “Öğrencilerin YAPA'dan aldığı toplam puan ile düzenli olarak kitap okuyup okumama durumları arasında anlamlı bir farklılık var mıdır?" alt problemine cevap aranmaya çalışılmıştır. Bunu belirlemek için yapılan bağımsız grup t-Testi sonuçları Tablo 17'de yer almaktadır.

Tablo 17. YAPA'dan alınan toplam puanın öğrencinin düzenli olarak kitap okuma durumuna göre farklılaşıp farklılaşmadığını belirlemek üzere yapılan bağımsız grup t testi sonuçları

\begin{tabular}{llcccccc}
\hline \multicolumn{2}{l}{ Kitap Okuma } & $\mathrm{N}$ & $\overline{\mathrm{X}}$ & $\mathrm{S}$ & $\mathrm{t}$ & $\mathrm{sd}$ & $\mathrm{p}$ \\
\hline \multirow{2}{*}{ 5. sınıf } & Evet & 263 & 35,21 & 11,53 &, 925 & 96,338 &, 108 \\
& Hayır & 60 & 32,78 & 10,23 & & & \\
\cline { 2 - 8 } 8. sınıf & Evet & 157 & 40,35 & 14,41 & $-1,450$ & 286,94 &, 487 \\
& Hayır & 136 & 39,19 & 14,05 & & & \\
\hline
\end{tabular}

Düzenli olarak kitap okumanın, yazılı anlatım düzeylerini üzerinde anlamlı bir etkisi olup olmadığını ortaya koymak için yapılan ilişkisiz örneklemler için t testinde, 5.sınıflarda düzenli olarak kitap okuyan öğrencilerin ortalaması $(\bar{X}=35,21)$, düzenli olarak kitap okumayan öğrencilerin ortalaması $(\bar{X}=32,78)$ arasında anlamlı bir fark yoktur $\left(t_{(321)}=0,925 p>0.05\right)$. Bu durumda 5. sınıf düzeyinde düzenli olarak kitap okuma durumunun yazılı anlatım düzeyi üzerinde anlamlı etkisinin olmadığını göstermektedir.

8.sınıflarda düzenli olarak kitap okuyan öğrencilerin ortalaması ( $\bar{X}=40,35$ ), düzenli olarak kitap okumayan öğrencilerin ortalaması $(\bar{X}=39,19)$ arasında anlamlı bir fark yoktur $\left(t_{(291)}=1,450\right.$, 
$p>0.05)$. Bu durumda 8.sınıf düzeyinde düzenli olarak kitap okuma durumunun yazılı anlatım düzeyi üzerinde anlamlı etkisinin olmadığını göstermektedir.

Bu araştırmada böyle bir sonuçla karşılaşmamızın birçok nedeni olabilir. Yazma becerisinin gelişiminde okuma çalışmalarının gerekliliğinin görülmemesi, yazma becerisiyle ilişkilendirilmemesi öğrencilerin yazma beceri düzeylerine etki etmemiş olabilir.

\section{Sonuç}

Araştırmanın dördüncü probleminde bazı değişkenler açısından öğrencilerin "Yazılı Anlatım Düzeyinin Belirlemek İçin Kullanılan Dereceli Puanlama Anahtarı"ndan aldıkları toplam puanları karşılaştırılarak istatiksel farklılaşma olup olmadığına bakılmıştır. Sonuç olarak;

a. Araştırmaya katılan öğrencilerin yazma beceri düzeyleri cinsiyet değişkeni açısından 5 . sınıflarda anlamlı bir farklııı göstermezken, 8. sınıflarda ise anlamlı bir farklılık göstermektedir. Ortaokul öğrencilerinin yazılı anlatım çalışmaların düzeylerinin değerlendirilmesinde cinsiyetin rol oynayıp oynamadığını belirlemeye yönelik yapılan istatiksel çalışmalarda kız öğrenciler lehine anlamlı bir fark ortaya çıkan bazı çalışmalar şunlardır: Mullis vd (2003), Bölükbaş (2006), Çocuk Vakfı (2006), Belet ve Yaşar (2007), Tok (2008) Arıcı ve Ungan (2008). Yılmaz (2008) ve Yasul (2014)'un çalışmalarında ise öğrencilerin cinsiyetleri ile yazılı anlatım becerileri arasında anlamlı bir ilişki tespit edilmemiştir.

b. Araştırmaya katılan öğrencilerin yazma beceri düzeyleri sınıf değişkeni açısından değerlendirildiğinde sınıf değişkeni açısından anlamlı bir farklılık göstermektedir. Dolayısıyla bu araştırmadan elde edilen sonuç yapılan araştırmaların bulgularını da destekler niteliktedir. Akyol (2010)'un da belirttiği gibi sınıf düzeyleri arttıkça öğrencilerin yazma becerileri de gelişmektedir. Ayrıca, öğrencinin sekizinci sınıfa kadar edindiği sözcük dağarcığı, dil becerisine ait kazanımlara sahip olma düzeyinin artması yazma becerisinin gelişimini desteklemiştir.

c. Araştırmaya katılan öğrencilerin aldıkları toplam puanlar, annenin eğitim durumuna göre anlamlı olarak farklılaşmaktadır. Annesi üniversiteden mezun olan öğrencilerin puanları, annesi okuryazar olmayan, annesi ilkokul ve ortaokuldan mezun olmuş öğrencilerden yüksek çıkmıştır. Ayrıca annesi liseden mezun olan öğrencilerin aldıkları puanlar, annesi ortaokuldan mezun olan öğrencilerin puanlarından yüksek çıkmıştır. Burada en yüksek puanlar annesi üniversiteden mezun olan öğrencilere aittir. Çalışmada annenin eğitim düzeyleriyle öğrencilerin yazma düzeyleri arasında anlamlı bir ilişkinin olduğu tespit edilmiştir. Burada çıkan sonuç çocuğun dil gelişimi üzerinde eğitimli annenin ne kadar 
önemli olduğunu göstermektedir. Annenin almış olduğu eğitim çocuğuyla kurduğu iletişime nitelik kazandırmakta ve çocuğun dilsel gelişimine katkı sağlamaktadır. Alanda yapılan diğer çalışmalar da bu sonucu destekler niteliktedir: Demir (2011), Tulgar (1997), Yasul (2014), Çelik (2012)'in çalışmalarında da benzer sonuçlar elde edilmiştir.

d. Araştırmaya katılan öğrencilerin aldıkları puanlar babanın eğitim durumuna göre anlamlı olarak farklılaşmaktadır. Gruplar birebir karşılaştırıldığında babası üniversiteden mezun olan öğrencilerin puanları babası okuryazar olmayan, babası ilkokul ve ortaokuldan mezun olmuş öğrencilerin puanlarından daha yüksektir. Ayrıca babası liseden mezun olmuş öğrencilerin puanları, babası ortaokuldan mezun olmuş öğrencilerin puanlarından yüksek çıkmıştır. Yazma beceri düzeyleri bakımından en başarılı grup ise babası üniversite mezunu olanlardır. Öğrencilerin yazma becerileri düzeyleri babanın eğitim düzeyine göre anlamlı bir farklılık oluşturmaktadır. Tulgar da (1997), Demir (2011) ve Yasul (2014), Çelik (2012) babanın eğitim durumunun yazma düzeyiyle doğru orantılı bir ilişkisi olduğu sonucuna ulaşmışlardır. Bu çalışmalarda da öğrencilerin babalarının öğrenim düzeyi arttıkça yazılı anlatım düzeylerin de arttığı tespit edilmiştir.

e. Araştırmaya katılan öğrencilerin aldıkları toplam puanlar ailenin gelir düzeyine göre anlamlı bir biçimde farklııı göstermektedir. 5.sınıflarda anlamlı farkın üst düzey gelir grubuyla orta düzey gelir grubu arasında, üst düzey gelir grubuyla alt düzey gelir grubu arasında, orta düzeyle alt düzey grubu arasında olduğu görülmüştür. 8.sınıflarda ise, anlamlı farkın orta düzey gelir grubuyla alt düzey gelir grubu arasında, üst düzey gelir grubuyla alt düzey gelir grubu arasında olduğu görülmüştür. Öğrencilerin yazılı anlatımlarında sosyo-ekonomik düzeylerinin etkili olup olmadığını belirlemeye yönelik olarak yapılan incelemede üst düzey gelir düzeyine sahip olan öğrencilerle alt düzeye sahip öğrenciler arasında istatiksel olarak anlamlı bir fark bulunmuştur. Aile sosyoekonomik bakımdan üst seviyeye çıktıkça öğrencinin yazılı anlatım düzeyinin de arttığı tespit edilmiştir. Bu durum sosyo-ekonomik düzeyin öğrencilerin yazılı anlatım becerileri etkilediğini göstermektedir. Buna benzer sonuçlar Bostancı (2003), Taner ve Başal (2005), Temur (2006), Çelik (2012), Bölükbaş (2006), Arıcı (2005), Arıcı ve Ungan (2008) 'de de tespit edilmiştir. Ailenin gelir düzeyi arttıkça çocuğuna sunduğu eğitim olanakları da artmaktadır. Maddi durumu iyi olan aileler, çocuklarına çalışma odası, çalışma masası gibi imkânları sağlayabilmektedirler. Bunların da böyle bir sonucun ortaya çıkmasında etkili olmuş olabilir. 
f. Araştırmaya katılan öğrencilerinin yazma beceri düzeyleri okulda kütüphane olma durumuna göre farklılaşmamaktadır. Yapılan literatür incelemesinde bu değişkenin kullanıldığı herhangi bir çalışmaya rastlanılmamıştır.

g. Araştırmaya katılan öğrencilerinin yazma beceri düzeyleri günlük tutma durumuna göre farklılaşmamaktadır. Bu sonuç Aktan (2013), Çelik (2012) çalışmalarına paralellik göstermektedir.

h. Araştırmaya katılan öğrencilerinin yazma beceri düzeyleri Yazarlık ve Yazma Becerileri dersi alma durumuna göre farklılaşmamaktadır. Yapılan literatür araştırmasında bu değişkenin kullanıldığı herhangi bir çalışmaya rastlanılmamıştır. Fakat Özonat ve Sis (2016:1898) yapmış oldukları çalışmada Yazarlık ve Yazma Becerileri dersini alan öğrencilerde çoğunlukla daha iyi kompozisyon yazma, Türkçe dersinin akademik başarısını arttırma, konuşma becerisinin gelişimi, yazma ve okuma becerilerinin gelişimi, yazım, noktalama ve dil bilgisi öğrenimini kolaylaştırma gibi kendilerine katkı sağladığı görüşünün varlığını tespit etmişlerdir.

i. Araştırmaya katılan öğrencilerinin yazma beceri düzeyleri evlerinde kitaplık olma durumuna göre farklılaşmamaktadır. Çelik (2012)'in çalışmasında ise evlerinde kitaplık bulunup bulunmama durumları ile öğrencilerin yazılı anlatım becerileri arasında anlamlı bir fark tespit edilmemiştir

j. Araştırmaya katılan öğrencilerinin yazma beceri düzeyleri düzenli kitap okuma durumuna göre farklılaşmamaktadır. Düzenli olarak kitap okuma durumunun yazılı anlatım düzeyi üzerinde anlamlı etkisinin olmadığını göstermektedir. Yasul'un (2014) çalışmasına paralellik göstermektedir. Nitekim daha önce yapılana birçok çalışmanın sonuçlarında ise Yılmaz (2012), Öztürk (2012)'ün düzenli olarak kitap okuma alışkanlığı ile yazlı anlatım becerisi arasında anlamlı bir ilişkinin olduğu tespit edilmiştir.

k. Araştırmaya katılan öğrencilerinin yazma beceri düzeyleri eve süreli yayın alma sıklığına göre anlamlı bir farklılık göstermektedir. Anlamlı farkın evine ayda bir yayın alan öğrencilerle evine hiç yayın almayan öğrenciler arasında, evine her gün yayın alan öğrencilerle evine ayda bir yayın alan öğrenciler arasında olduğu tespit edilmiştir. Evlerine süreli yayın alınan öğrencilerin yazma düzeyleri evine hiç süreli yayın girmeyenlere göre anlamlı bir şekilde daha yüksek olduğu tespit edilmiştir. 


\section{Kaynaklar}

Akyol, H. (2010). Türkçe Öğretim Yöntemleri. Ankara: Pegem Yayıncılık.

Aktan, E. (2013). Ortaöğretim 9. Sınıf Öğrencilerinin Yaratıcı Yazma Becerileri Üzerine Bir Araştırma (Kütahya İli Örneği). Adıyaman Üniversitesi Sosyal Bilimler Enstitüsü Dergisi, 2(3), 701-731.

Arıcı, A.F. (2005). Türkçe Öğretiminde Kullanılan Strateji-Yöntem ve Teknikler. Atatürk Üniversitesi Sosyal Bilimler Enstitüsü Dergisi, 7(1), 299-307.

Arıcı A. F. ve Ungan S. (2008). İlköğretim İkinci Kademe Öğrencilerinin Yazılı Anlatım Çalışmalarının Bazı Yönlerden İncelenmesi. Dumlupınar Üniversitesi Sosyal Bilimler Enstitüsü Dergisi, 20, 317-328.

Babbie, E. (1990). Social research methods. New York: Basic Books.

Belet, D. ve Yaşar Ş. (2007). Öğrenme Stratejilerinin Okuduğunu Anlama ve Yazma Becerileri ile Türkçe Dersine İlişkin Tutumları. Eğitimde Kuram ve Uygulama Eğitim Bilimleri Dergisi, (1), 69-86.

Bostancı, G. (2003). Ergenlik Dönemindeki Çocukların Sosyoekonomik Şartlar Çerçevesinde Dil Kullanma Biçimleri. Yayınlanmamış Yüksek Lisans Tezi. Gazi Üniversitesi Sosyal Bilimler Enstitüsü, Ankara.

Bölükbaş, F. (2006). Öğrencilerin Okuma ve Yazmaya Yönelik Tutumlarının Bazı Değişkenler Açısından Değerlendirilmesi. Çağdaş Eğitim, 333, 32-39.

Büyüköztürk, Ş., Çokluk, Ö. ve Köklü, N. (2010). Sosyal Bilimler Için Istatistik. Ankara: Pegem Akademi.

Can, A. (2014). SPSS ile Bilimsel Araştırma Sürecinde Veri Analizi. Ankara: Pegem Yayıncılık.

Çelik, V. (2000). Okul Kültürü ve Yönetimi. Ankara: Pegem Yayıncılık.

Çocuk Vakfı (2006). Türkiye’nin Okuma Alışkanlığı Karnesi. İstanbul: Çocuk Vakfı.

Demir, T. (2011), ilköğretim Öğrencilerinin Yaratıcı Yazma Becerileri ile Yazma Özyeterlik Algısı ve Başarı Amaç Yönelimi Türleri Iliş̧kisinin Değerlendirilmesi. Yayınlanmamış Doktora Tezi. Gazi Üniversitesi Eğitim Bilimleri Enstitüsü, Ankara.

Field, A. (2002). Discovering Statistics Using Spss. Sage Publications Ltd, UK: London.

Karaalioğlu, S. K. (1978). Yazmak ve Konuşmak Sanatı Kompozisyon. İstanbul: İnkılap Kitabevi

Karasar, N. (1998) Nitel Araştırma Yöntemi. Ankara: Nobel Yayın Dağıtım.

Karasar, N. (2005) Nitel Araştırma Yöntemi. Ankara: Nobel Yayın Dağıtım.

Keçik, İ. ve Uzun, L. (2001). Türkçe Sözlü ve Yazılı Anlatım. Eskişehir: Anadolu Üniversitesi Yayınları.

Mertkan, Ş. (2012). Karma Araştırma Tasarımı. Ankara: Pegem Akademi.

Mullis, I.V., Martin, M. O., Gonzales, E. J. and Kennedy, A. N. (2003), PIRLS 2001 Internatıonal Report. Boston: International Study Center.

Öztürk Karakoç, B. (2012). İlköğretim İkinci Kademe Öğrencilerinin Yazma Kaygılarının Çeşitli Değişkenler Açısından İncelenmesi. Çukurova Üniversitesi, Sosyal Bilimler Enstitüsü Dergisi, 21, 59-72.

Özonat, Z. ve Sis, N. (2016). Yazarlık ve Yazma Becerileri Dersi Üzerine Bir Araştırma. Turkish Studies, 11, 1308-2140.

Sencer, M. ve Sencer, Y. (1978). Toplumsal Araştırmalarda Yöntembilim. Ankara: TO-DAIE.

Shrout, P. and Fleiss, J. L. (1979). Intraclass Correlatıonueses In Assesing Rater Reliability. Psychologial Bulletin, $86(2), 420-428$.

Şencan, H. (2005). Sosyal ve Davranışsal Ölçümlerde Güvenirlilik ve Geçerlilik. Ankara: Seçkin Yayıncılık.

Taner, M. ve Başal, H. A. (2005). Farklı Sosyo-Ekonomik Düzeylerde Okulöncesi Eğitimi Alan ve Almayan İlköğretim Birinci Sınıf Öğrencilerinin Dil Gelişimlerinin Cinsiyete Göre Karşılaştırılması. Uludağ Üniversitesi Eğitim Fakültesi Dergisi, 18 (2), 395-420. 
Temur, T. (2001). Ilköğretim 5. sınıf öğrencilerinin yazılı anlatım beceri düzeyleri ile okul başarıları arasındaki ilişki. Yayımlanmamış Yüksek Lisans Tezi. Ankara Üniversitesi, Ankara.

Temur, T. (2006). Ilköğretim 4. Ve 5. Sınıf Öğrencilerinin Yazı Dilindeki Kelime Hazinelerinin Bazı Değişkenler Açısından Incelenmesi. Yayınlanmamış Doktora Tezi. Gazi Üniversitesi, Ankara.

Tok, Ş. (2008). Not Tutma ve Bil-i̇ste-Öğren (BiÖ) Stratejilerinin Tutum ve Akademik Başarıya Etkisi. Hacettepe Üniversitesi Eğitim Fakültesi Dergisi, 34, 244-253.

Tulgar, B. (1997). Yaratıcı Drama Eğitimim Alan ve Almayan Ergenlerin Yaratıcılıklarının Bazı Değişkenlere Göre incelemesi. Yayınlanmamış Yüksek Lisans Tezi. Ankara Üniversitesi Fen Bilimleri Enstitüsü, Ankara.

Yasul, A. F. (2014). İlkokul 4. Sınıf Öğrencilerinin Öyküleyici Metin Yazma Becerilerinin Değerlendirilmesi (Muş ili merkez ilçesi örneği). Yayınlanmamış Yüksek Lisans Tezi, İnönü Üniversitesi Sosyal Bilimler Enstitüsü, Malatya.

Yıldırım, A. ve Şimşek, H. (2005). Sosyal Bilimlerde Nitel Araştırma Yöntemleri. Ankara: Seçkin Yayınları.

Yılmaz, K. S. (2008). Ilköğretim Altıncı Sınıf Öğrencilerinin Öyküleyici Metin Yazma Becerileri. Yayınlanmamış Yüksek Lisans Tezi. Gazi Üniversitesi, Eğitim Bilimleri Enstitüsü, Ankara.

Yılmaz, Y. (2012). Kuramdan Uygulamaya Türkçe Öğretimi. Ankara: Pegem Akademi Yayınları.

\section{Extended Abstract Introduction}

The present study aimed to determine the variables that affect sentence, paragraph and text formation levels of middle school students. The study sample included 5th and 8th grade students attending middle schools at Malatya province central district.

\section{Method}

Personal Information Form and "Grade Score Key to Determine Written Expression Levels" scale, developed by the author, were used to collect the study data. In the study, written expressions of the students were analyzed with quantitative methods. The study data were tested with one-way ANOVA, a parametric test, and independent samples t-test analysis. The study findings that there was a significant impact of gender, grade level, presence of a library at home, socio-economic level, mother's education level, father's education level and frequency of purchasing periodicals on written expression levels of 5 th and 8th grade students.

\section{Result and Discussion}

In the fourth research problem, the statistical differences between the total Grade Score Key to Determine Written Expression Levels scale scores of the students were compared based on certain variables. The following findings were obtained:

a. There was no significant difference between the writing skill levels of participating $5^{\text {th }}$ grade students based on the gender variable, while the difference between the writing skill levels of $8^{\text {th }}$ grade students was significant based on the same variable.

b. The difference between the writing skill levels of participating students were significant based on the grade level variable.

c. The total scores of participating students significantly differed based on the education level of the mother. The scores of the students whose mothers were college graduates were higher when compared to those of the students whose mothers were illiterate or primary or middle school graduates. Furthermore, the scores of the students whose mothers were high school graduates were higher when compared to those of the students whose mothers were middle school graduates. The students whose mothers were college graduates scored the highest points in the scale. In the study, it was determined that there was a significant correlation between the education level of the mother and students' writing levels. Thus, the finding suggested the significant impact of an educated mother on the language development of the child. The education of the mother improves the quality of the communication between the child and the mother ad contributes to the lingual development of the child.

d. The total scores of participating students significantly differed based on the education level of the father. Paired comparison of the groups demonstrated that the scores of the students whose fathers were college graduates were higher when compared to those of the students whose fathers were illiterate or primary or middle school graduates. Furthermore, the scores of the students whose fathers were high school graduates were higher when compared to those of the students whose 
fathers were middle school graduates. The students whose fathers were college graduates had the highest writing skill levels. There was a significant difference between the writing skill levels of the students based on father's education level.

e. The total scores of participating students significantly differed based on the family income. Among the $5^{\text {th }}$ grade students, it was observed that there were significant differences between the scores of high income and middle income students, high income and low income students, and between the middle income and low income students. Among the $8^{\text {th }}$ grade students, it was observed that there were significant differences between the scores of middle income and low income students, and high income and low income students. Analysis conducted to determine whether the socio-economic levels of the students were effective on their written expressin skills demonstrated that there was a statistically significant difference between high income and low income students. It was determined that written expression levels of the students increased with the increase in the socio-economic level of the family. Thus, it was determined that the socio-economic level had an impact on written expression skills of the students.

f. There was no significant difference between the writing skill levels of participating students based on the presence of a library at the school. Literature review demonstrated no previous studies that utilized that particular variable.

g. There was no significant difference between the writing skill levels of participating students based on whether they kept a diary.

h. There was no significant difference between the writing skill levels of participating students based on whether they took the Writing and Writing Skills Course. Literature review revealed no previous studies that utilized that particular variable.

i. There was no significant difference between the writing skill levels of participating students based on the presence of a library at home.

j. There was no significant difference between the writing skill levels of participating students based on whether they read books. Thus, it was determined that reading books regularly did not have a significant impact on written expression levels.

k. There was a significant difference between the writing skill levels of participating students based on the habit of purchasing periodicals at home. It was determined that the significant difference was between those who purchased periodicals once a month and those who never purchased periodicals and those who purchased periodicals every day and those who purchased periodicals once a month. It was observed that the writing levels of the students who purchased periodicals were significantly higher when compared to those who never purchased periodicals. 